excused for entering upon these personal details, as I give them to show that I have not been hasty in coming to a conclusion." _ "Origin of Species," p. I, ed. I859.

What could more completely throw us off the scent of the earlier evolutionists, or more distinctly imply that the whole theory of evolution that follows was an original growth in $\mathrm{Mr}$. Darwin's own mind?

Mr. Romanes implies that I imagine Mr. Darwin to have "entered into a foul conspiracy with Dr. Krause, the editor of Kosmos," as against my book "Evolution, Old and New," and later on he supposes me to believe that I have discovered what he calls, in a style of English peculiar to our leading scientists, an "erroneous conspiracy." The idea of any conspiracy at all never entered my mind, and there is not a word in "Unconscious Memory" which will warrant Mr. Romanes' imputation. man may make a cat's paw of another without entering into a conspiracy with him.

Later on Mr. Romanes says that I published " Evolution, Old and New," "in the hope of gaining some notoriety by deserving, and perhaps receiving, a contemptutous refutation " from Mr. Darwin. I will not characterise this accusation in the terms which it merits.

I turn now to Dr. Krause's letter, and take its paragraphs in order.

I. Dr. Krause implies that the knowledge of what I was doing could have had nothing to do with Mr. Darwin's desire to bring out a translation of his (Dr. Kranse's) essay, inasmuch as Mr. Darwin informed him of his desire to have the essay translated "more than two months prior to the publication of" my book, "Evolution, Old and New." This, I have no doubt, is true, but it does not make against the assumption which I made in "Unconscious Memory," for "Evolution, Old and New," was announced fully ten weeks before it was published. It was first announeed on February 22, 1879, as about to contain "copious extracts" from the works of Dr. Erasmus Darwin and a comparison of his theory with that of his grandson, Mr. Charles Darwin. This announcement would show Mr. Darwin very plainly what my book was likely to contain; but Dr. Krause does not say that Mr. Darwin wrote to him before February 22, 1879 - presumably because he cannot do so. I assumed that Mr. Darwin wrote somt where about March $\mathrm{r}$, which would still be "more than two montbs before" the publication of "Evolntion, Old and New."

2. Dr. Krause says I assume that "Mr. Darwin had urged him to insert an underhand attack upon him (Mr. Butler)." I did not assume this; I did not believe it ; I have not said anything that can be constrned to this effect. I said that Dr. Krause's concluding sentence was an attack upon me; Dr. Krause admits this. I said that under the circumstances of Mr. Darwin's preface (which distinctly precluded the reader from believing that it could be meant for me) the attack was not an open, but a covert one ; that it was spurious-not what through Mr. Darwin's preface it professed to be ; that it was antedated ; that it $x$ as therefore a spurious and covert attack upon an opponent interpolated into a revised edition, the revision of which had been concealed. This was what I said, but it is what neither Mr. Romanes nor Dr. Krause venture to deny. I neither thought nor implied that Mr. Darwin asked Dr. Krause to write the attack. This would not be at all in Mr. Darwin's manner.

3. Dr. Krause does not deny that he had my book hefore him when he was amending his article. He admits baving taken a passage from it without acknuwledgment. He calls a page and a balf " a remark," I call it " a passage." He says he did not take a second passage. I did not say he had; I only said the second passage was "presumably" taken from my book, whereas the first "certainly" was so. The presumption was strong, for the passage in question was not in Dr. Kranse's original article; it was in ny book, which Dr. Krause admits to have had before him when amending his article, and it came out in the amended article ; but if Dr Krause says it is merely a coincidence, of course there is an end of the matter.

4. Dr. Krause, taking up the cudgels for Mr. Darwin, does not indeed deny the allegations I bave made as to the covertness, and spuriousness, and antedating of the attack upon myself, but contends that "this is not due to design, but is simply the result of an oversight"; he is good enough to add that this oversight "could only be most agreeable" to myself. When I am not in the wrong I prefer my friends to keep as closely as they can to the facts, and to leave it to me to judge whether a modification of them would be "most agreeable" to me or no. What, I wonder, does Dr. Krause mean by oversight? Does he mean that Mr. Darwin did not know the conclusion of Dr. Krause's essay to be an attack upon myself? Dr. Krause says, "To every reader posted up in the subject this could not be doubtful," meaning, I suppose, that no one could doubt that I was the person aimed at. Does he mean to say Mr. Darwin did not know he was giving a revised article as an unrevised one? Does he mean that Mr. Darwin did not know he was saying what was not true when he said that my book appeared sub sequently to what he was then giving to the public? Does he pretend that Mr. Darwin's case was not made apparently better and mine worse by the supposed oversight? If the contention of oversight is possible, surely Mr. Darwin would make it himself, and surely also he would have made it earlier? Granting for a moment that an author of Mr. Darwin's experience could be guilty of such an oversight, why did he not when it was first pointed out, more than twelve months since, take one of the many and easy means at his disposal of repairing in public the injury he had publicly inflicted? If he had done this he would have heard no more about the matter from me. As it was, he evaded my gravamen, and the only step he even proposed to take was made contingent upon reprint of his book being called for. As a matter of fact a reprint has not been called for. Mr. Darwin's only excuse for what he had done, in his letter to myself, was that it was "so common a practice" for an author to take an opportunity of revising his work that "it never occurred" to him to state that Dr. Krause's article had been modified. It is doubtless a common practice for authors to revise their work, but it is not common when an attack upon an opponent is known to have been interpolated into a revised edition the revision of which is concealed, to state with every circumstance of distinctness that the attack was published prior to the work which it attacked.

To conclude : I suppose Mr. Romanes will maintain me to be so unimportant a person that Mr. Darwin has no call to bear in mind the first principles of fair play where I am concerned, just as we need keep no faith with the lower animals. If $\mathrm{Mr}$. Darwin chooses to take this ground, and does not mind going on selling a book which contains a grave inaccuracy, advantageous to himself and prejudicial to another writer, withont taking any steps to correct it, he is welcome to do so as far as I am concernedhe hurts himself more than he hurts me. But there is another aspect of the matter to which I am less indifferent: I refer to its bearing upon the standard of good faith and gentlemanly conduct which should prevail among Englishmen-and perhaps amony Germans too. I maintain that Mr. Darwin's recent action and that of those who, like Mr. Romanes, defend it, has a lowering effect upon this standard.

S. BUtler

\section{Geological Climates}

$W_{\text {HEN }}$ a reader of the intelligence of $\mathrm{Mr}$. Wallace misunderstands my words it becomes plain to me they have failed to convey my meaning. I lo not accept the interpretation he has put upon them, nor do I admit that even that interpretation would tell so much in favour of his theory as he supposes.

As however I agree with him that the question is far too large to be fully discussed in your columns, I shall allow the controversy, so far as I am concerned, to terminate, and shall publish my detailed views on geological climate in another way.

Trinity College, Dublin, January 27 Samuel Haughton

\section{On the Spectrum of Carbon}

IN the discussions on the spectrum of carbon which have recently appeared in your journal much stress is laid on the impossibility of volatilising that substance by any heat which man can produce. I think this assumption is not warranted by experience. Two or three facts in Despretz' account of a remarkable set of exreriments which he made about thirty year ago, seem to me to show it to be unfounded. This is given in the Comptes rendus, vol. xxviii. He exposed rods of anthracite to the action of 125 Bunsens (zincs $5 \frac{1}{4} \mathrm{in}$. high) and also to the solar focus of an annular lens $36 \mathrm{in}$. diameter. The rods bent under the combined action, and even appeared to fuse! In vol. xxix. he describes experiments with rods of sugar-charcoal under a battery of 500 similar cells. The electric egg was covered suddenly with a hard block crystalline powder.

He thinks attempts to fuse carbon should be made in condensed nitrogen and in metallic vessels. In the same volume he says that with 600 cells rods of sugar charcoal bend-swell at the 